INVESTIGANDO ALGUNS DOS PARÂMETROS DO RIO KURA

(“MTKVARI") EM DOIS PAÍSES VIZINHOS - GEÓRGIA E

TURQUIA, EM TERMOS DE QUÍMICA AMBIENTAL

\title{
RESEARCHING SOME OF THE PARAMETERS OF KURA ("MTKVARI”) RIVER IN TWO NEIGHBOURING COUNTRIES - GEORGIA AND TURKEY, IN TERMS OF ENVIRONMENTAL CHEMISTRY
}

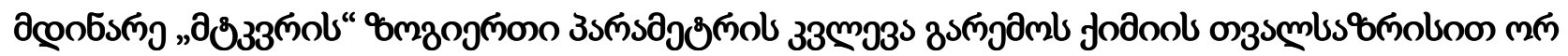

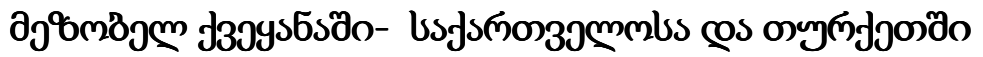

\author{
KUPATADZE,Ketevan ${ }^{1 *}$; KIZILÖZ , Burak² \\ 1 llia State University, Georgia, Tbilisi \\ Kakutsa Cholokashvili Ave 3/5. Tbilisi 0162, Georgia \\ (phone: +955 599 290905)
}

${ }^{2}$ Kocaeli Great Municipality, Water and Sewerage Administration, Turkey, Kocaeli

Guzeller Neighbourhood, Şehit Mevlüt Duru Road, Building No: 10, Gebze (District ) / Kocaeli

\author{
* Corresponding author \\ e-mail: Ketevan_kupatadze@iliauni.edu.ge
}

Received 2 October 2018; received in revised form 10 November 2018; accepted 12 November 2018

\section{RESUMO}

O artigo examina alguns dos indicadores do Rio Mtkvari em termos de química ambiental. O estudo abrange o período 2016-2017 completo e o primeiro semestre de 2018 na Geórgia e na Turquia. Em particular, os dados foram coletados a partir de pontos de amostragem em Tbilisi e Karsi. No contexto da Geórgia, para nós, a situação existente em Tbilisi foi muito mais interessante, pois a contaminação por fatores antrópicos adicionais está aumentando aqui. Além disso, o peixe capturado em Mtkvari, em Tbilisi, é usado como alimento e para venda pela população local. Respectivamente, a condição do rio afeta a saúde da população. Mktvari é um rio comum para dois países vizinhos (também flui no terceiro país, no entanto, limitamo-nos apenas à Turquia e à Geórgia), pelo que o seu estudo ambiental é considerado crucial. Parâmetros químicos foram definidos no local. Outros parâmetros foram determinados no laboratório. O transporte de amostras foi realizado através da metodologia da International Standard Organization (ISO). Os resultados obtidos indicam contaminação moderada.

Palavras-chave: Condição do Rio Mtkvari, química ambiental, poluentes fluviais.

\section{ABSTRACT}

The article examines some of the indicators of Mtkvari River in terms of environmental chemistry. The study covers full 2016-2017 and the first half of 2018 in Georgia and Turkey. In particular, the data were collected from sampling points in Tbilisi and Karsi. In the context of Georgia, for us, the existing situation in Tbilisi was far more interesting, as contamination by additional anthropogenic factors is getting increased here. In addition to this, the fish caught in Mtkvari in Tbilisi is used as food and for sale by the local population. Respectively, the river condition affects the health of the population. Mktvari is a common river to two neighbor countries (it flows in the third country as well, however, we limited ourselves to Turkey and Georgia only), therefore its environmental study is deemed to be crucial. Chemical parameters were defined on site. Other parameters were determined in the lab. Transportation of samples was conducted through the International Standard Organization (ISO) methodology. The obtained results showed moderate contamination.

Keywords: Condition of Mtkvari River, environmental chemistry, river pollutants. 


\section{mogoyga}

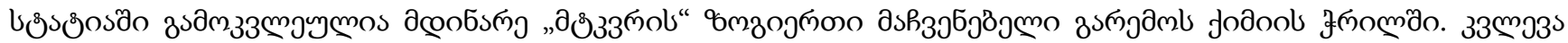

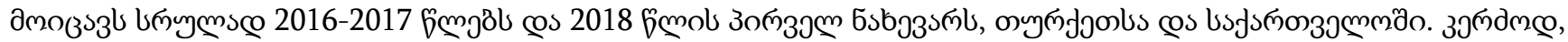

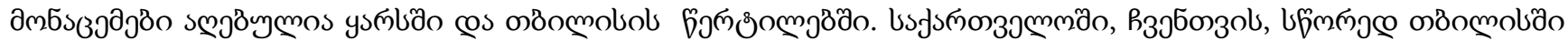

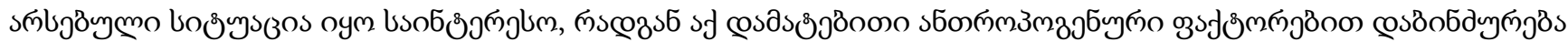

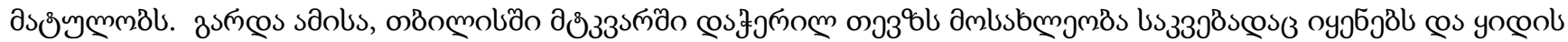

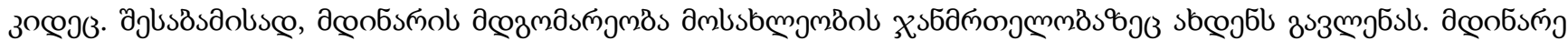

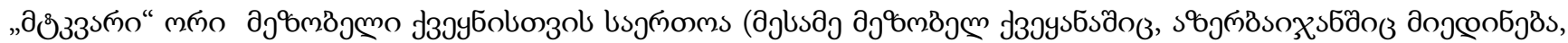

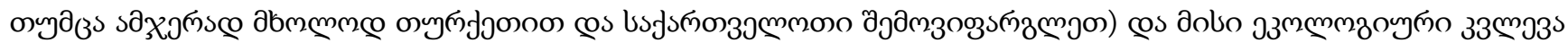

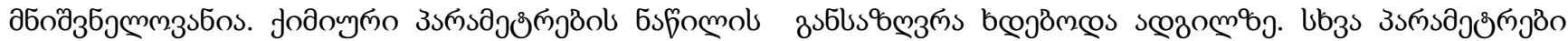

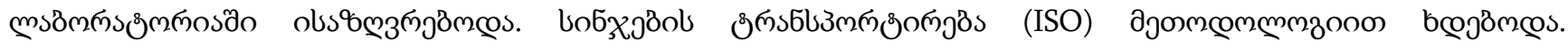

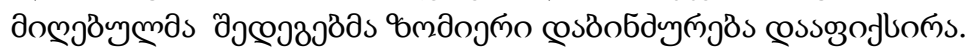

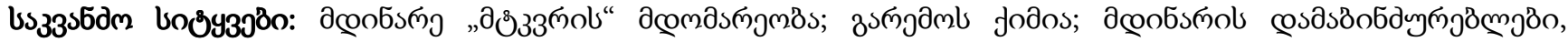
deoobsmol fymol bsmolbo.

\section{INTRODUCTION}

Kura - the largest river of the South Caucasus, belonging to Caspian Sea basin, originates in Turkey, east slope of the mountain Kizil-Gyadik, at the height of $2742 \mathrm{~m}$. above sea level. Passing through the territory of Georgia, it flows into the Caspian Sea in Azerbaijan. The river Kura basin includes the Great Caucasian Ridge, Armenian upland region and intermountain tectonic depression. The river basin covers the part of the territory in Turkey, Georgia, part of the territory in Iran, most of the Azerbaijanian territory and the whole territory of Armenia. The total length of the river Kura is $1364 \mathrm{~km}$, including $185 \mathrm{~km}$ in Turkey, $390 \mathrm{~km}$ in Georgia and $789 \mathrm{~km}$ in Azerbaijan [1]. The natural water flow of the river Kura in Turkey (up to Georgian border) makes average 1,04 $\mathrm{km}^{3} /$ year $(5,3 \%$ of total water flow). During many years water flow in Georgia, near Tbilisi, makes $203 \mathrm{~m}^{3} / \mathrm{sec}$ or $6,39 \mathrm{~km}^{3} /$ year.

The name Kura is related to the name of Cyrus the Great, emperor of Persia, The Georgian name of Kura is Mt'k'vari [2] It rises in northeastern Turkey in a small valley in the Kars Upland of the Lesser Caucasus. It flows (see Figure 1) west, then north and east past Ardahan, and crosses into Georgia. It arcs to the northwest, then into a canyon near Akhaltsikhe where it starts to run northeast in a gorge for about 75 kilometers (47 mi), spilling out of the mountains near Khashuri. It then arcs east and starts to flow east-southeast for about
120 kilometers $(75 \mathrm{mi})$, past Gori, then near Mtskheta, flows south through a short canyon and along the west side of Tbilisi, the largest city in the region. The river flows steeply southeast past Rustavi and turns eastward at the confluence with the Khaki River, crossing the Georgia-Azerbaijan line and flowing across grasslands into Shemkir reservoir and then Yenikend reservoir [3].

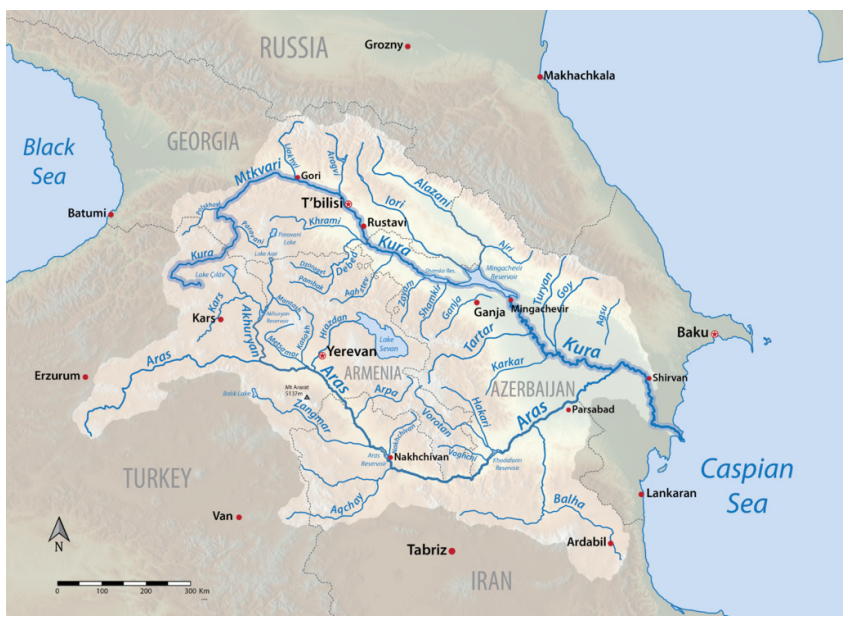

Figure 1. The river Kura and its borders

The ecological condition of the Mtkvari River is very important, having an international significance, as mentioned above. It is being used in industry, agriculture and for energy purposes. In addition, the population actively fishes in this river, both for consumption and sale. Respectively, the pollution level of the Mtkvari river in terms of environmental chemistry is extremely important. The reasons of pollution are 
diverse but mainly anthropogenic. Pollution is conditioned by anthropogenic factors (especially in deposit surrounding areas), agricultural sector, household chemistry, wastewater, hospital waste and activities of municipal enterprises. There are few wastewater treatment plants functioning in only several places of Georgia. In that respect, the situation is much better in Turkey, operating not only conventional treatment systems but natural ones as well $[4,5]$.

\section{EXPERIMENTAL SECTION}

In Turkey, the Mtkvari River samples were analyzed in the lab of State Water Administration Kars regional offices. The research period covered full 2016-2017 and the first half of 2018, according to seasons (Table 1).

The Mtkvari River sampling in Tbilisi city was conducted at two sampling points: Vakhushti Bridge, Metekhi Bridge. The samples were taken in 2016-2017 and in the first half of 2018, according to all the four seasons. The samples were analyzed through analytical chemistry methods in llia State University. However, part of the data reviewed by the article was retrieved from official data of the National Environmental Agency [6]. More specifically, heavy metal concentrations were extracted from the data of the National Environmental Agency. Ammonium nitrogen, general water hardness according to calcium, metal discovery reactions and the amount of aluminum sulfate were determined in Ilia State University. The data on Georgia, particularly on Tbilisi are reflected in Table 2.

\section{RESEARCH METHODS}

In the Kars research center, $\mathrm{pH}, \mathrm{BOD}$, the temperature was measured directly during the sampling. Other used measurement methods are under Turkish Standards Institution (TSE) [7].

In Georgian part of the research, pH, BOD, the temperature was measured directly during the sampling. The analysis for defining cations, anions and water hardness were conducted in llia State University. Their protocols are based on analytical chemistry method, mainly in terms of quality (Colorimetric) and quantity (Titrimetric) $[8,9]$. The existence of heavy metals was established through discovery reactions, and the existing amount was directly taken from the environmental agency website, where heavy metals in water samples were determined using inductively coupled plasma optical emission spectrometry (ICP-OES) on the basis of ISO 11885: 2007 standard [10].

\section{RESULTS AND DISCUSSION:}

In the Turkish part, according to the samples analyzed in Kars, during the course of three research years, BOD amount was within the norms, indicating a healthy microflora in the water. Maximum mineralization was observed in November-December of 2016. It was also reported in early winter of 2017. Maximum mineralization during the first half of 2018 falls on the month of June.

Ammonium $\left(\mathrm{NH}^{4+}\right)$ is an ionized form of ammonia $\left(\mathrm{NH}_{3}\right)$ and is mainly generated during high water acidity. In other words, during the low level of $\mathrm{pH}$, more molecules of ammonia transform to ammonium ions and on the contrary, during a high level of $\mathrm{pH}$, the quantity of ammonia increases. The increased amount of ammonium ion may be toxic to organisms living in the river. BOD will also increase respectively. That's why it is so crucial to measure ammonium nitrogen. Amount of ammonium nitrogen slightly exceeds the maximum permissible level. Maximum amount was captured in November 2016, in August of 2017 and in June of 2018. As for the analyzed metals, they range within the maximum permissible levels. There was a slight increase in the amount of copper and manganese in August of 2016 and in June of 2017. The rest of the metals examined were within the norms, there was no evidence of the most dangerous metalszinc, cadmium, and mercury. These metals are recognized by UN as the most dangerous metals and a special threat to flora and fauna in water, and therefore to a human $[11,12]$.

In Tbilisi, maximum mineralization of Mtkvari River at Vakhushti Bridge was observed in December of 2016. The concentration of ammonium nitrogen in most of the samples exceeded the maximum permissible limit. Maximum value $1.213 \mathrm{mgn} / \mathrm{l}$ was reported in November. It is important to define the concentration of heavy metals. Their existence, first of all, leads to the intoxication of organisms and fish living in the river that can be reflected on human health as well, bearing in mind that the fish caught in the river is used as food and for sale by the population. 
Heavy metals can get in the river as a result of industrial activities. As for the aluminum, it is included in the ingredients of low price shampoos, shower gels, and consequently, gets in surface water through the wastewater. Amount of certain metals was within the norms, however, $\mathrm{Ca}$ exceeded the norm 1.9 times. There was also a high volume of copper (compared to the limits specified in the resolution of Government of Georgia). Out of sulfates, the noteworthy is aluminum sulfate, which from the so-called house chemistry gets in wastewater and ultimately in the river. Its volume as per the resolution of the Georgian government [13] was within the norms.

BOD indicates the amount of oxygen dissolved in the river [14], conditioning the balance between the river, vegetation, and animals living in it, i.e. ecosystem. According to the results, the BOD amount was satisfactory. Maximum mineralization in the samples taken from the same place was observed in September and July of 2017 and 2018, 461.37 and 527.42, thus, July indicator was slightly above the limit.

It is important to define the concentration of heavy metals. The increased amount of copper was also observed (compared to the norms specified in the resolution of the Government of Georgia). From sulfates, aluminum sulfate should be noted, getting into wastewater from the socalled household chemistry, and consequently ending up in the Mktvari River. Its amount was within norms according to the resolution of Georgian Government.

Hereof, the indicator of July 2018 was slightly above the limit. The amount of ammonium nitrogen was less, compared to 2016. BOD amount was satisfactory. The amount of aluminum sulfates was increased in 2017 , while the amount above the maximum limit was observed in March. In 2018 this value is within the norms, while it is steal increased in spring. Amount of other defined metals are within the norms. However, there is a slight increase in copper (compared to the norms specified in the resolution of the Georgian Government. Monitoring of metals, especially the heavy ones, is extremely important, as, in addition to already mentioned anthropogenic factors, they can get into water from the air as well. Air pollution in Georgia, especially in recent years, has acceded the norms (http://nea.gov.ge/ge/home/).
In 2016, the maximum value of mineralization at Metekhi Bridge - $420.7 \mathrm{mg} / \mathrm{m}$ was recorded in December. The maximum value of ammonium nitrogen $0.74 \mathrm{mg} \mathrm{N} / \mathrm{L}$ was also observed in December. Mineralization is maximum in summer and autumn; it comparatively decreases in winter and spring, which can be due to frequent rainfall. The Mtkvari River belongs to a group of polluted rivers, which is attributable to anthropogenic factors. As for the metals, the amount of calcium was increased in this area as well, the concentration of other metals varied within the norms. In the case of copper, an increase was still observed. BOD amount is satisfactory. The amount of aluminum sulfate is within the norms and slightly differs from those in the samples taken from Vakhushti Bridge. Maximum mineralization in samples of 2017 and 2018 was recorded in June and July (322.4 and 447.2) however all values varied within the norms. Neither the amount of ammonium nitrogen was substantially changed. BOD amount was satisfactory. The number of aluminum sulfates was increased in 2017 , with the value above the maximum indicator observed in a month, however, its amount is still within norms in 2018, and the increase is recorded again in spring. The amount of other measured metals are within the norms.

The increase of heavy metal - copper is not surprising at all. Particularly polluted are Mashavera and Kazretula Rivers with copper and other heavy metals. They are contaminated with heavy metals, including copper by LLC "Madneuli (the current name "RMG Copper"). This company was founded in 1975 and is engaged in gold and copper extraction from the query. Some part of them flows into Mtkvari. Although the abovedescribed indicators were observed in the samples taken in Tbilisi, contamination was not so alarming (see Figure 2, 3, 4)

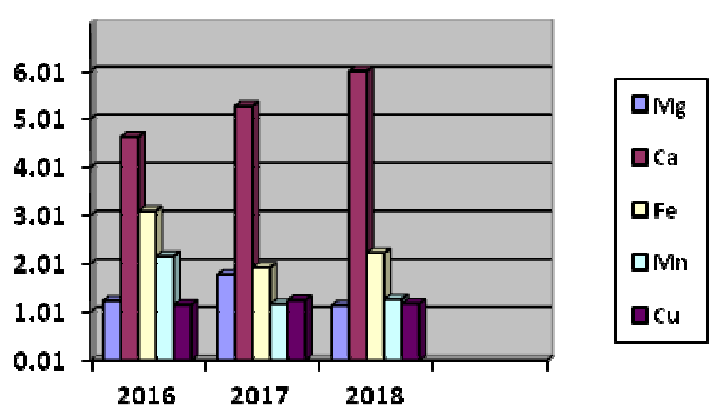


Figure 2. Determine metals Vakhushti Bridge
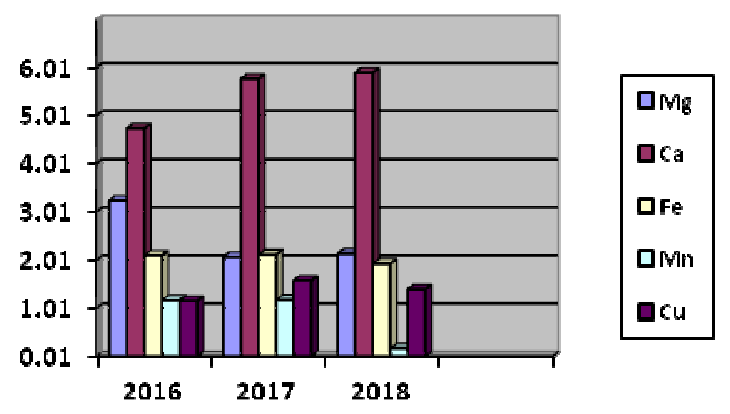

Figure 3. Determine metals Metechi Bridge

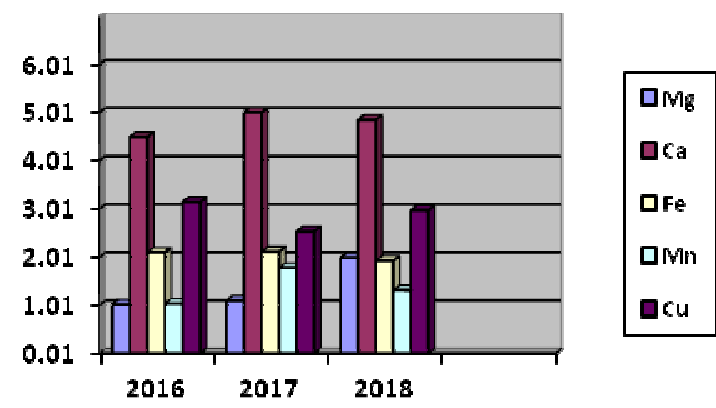

Figure 4. Determine metals at Kars in Turkey

According to the analysis of both countries, Mtkvari is a carbonated river, belonging to a calcium group, which is confirmed by increased levels of the mentioned metallic ions. Hardness increase was especially acute in spring and autumn and it applied to both countries. $\mathrm{PH}$ value was close to 8.5 , which is also considered to be in the norm. However, an increase was also reported time by time, being reflected on ammonium nitrogen indicator.

It is an important fact that in both countries there is no evidence of pollution with such heavy metals, like zinc, cadmium, and mercury. They constitute the so-called "thyol" poisons and can remain at the protein level in the body. The period of their semi-decomposition in the human body ranges from 100 to 150 days.

The color of Mtkvari river in Georgia is brown grayish, sometimes, particularly after heavy rains, floating solid particles are also observed, confirming anthropogenic pollution. The color of the river in Karsi is greenish-brown, mechanical contamination in the mentioned specific point is less but still noticeable.
As it was mentioned the fish caught in the river is used as food and for sale by the population. Heavy metals may accumulate in fish species, enter the food chain and cause serious harm to human health when the contamination content and exposure are significant $[15,16]$. The levels of heavy metal accumulation in fish depend on the growth rate, metabolism, feeding pattern and ecological requirements of a given fish species. The harmful effect of trace elements, when consumed above the recommended limit, can be toxic (acute, chronic or sub-chronic), and heavy metals can be a neurotoxin, carcinogenic, mutagenic or teratogenic. The general symptoms of humans related to metal [e.g., $\mathrm{Cd}, \mathrm{Pb}, \mathrm{As}, \mathrm{Hg}$, $\mathrm{Zn}, \mathrm{Cu}$ and aluminum (Al)] poisoning include vomiting, convulsions, paralysis, ataxia, hemoglobinuria, gastrointestinal disorder, diarrhea, stomatitis, tremor, depression, and pneumonia.

Theoretically for finding out how much heavy metals can be arrived in the human body after using fish in food from the river Kura during one month, can be calculated by the equation (see Eq.1,2,3,4).

Suppose person weighing $80 \mathrm{~kg}$, he/she eats $0,5 \mathrm{~kg}$ of fish containing $0,5 \mu \mathrm{g} / \mathrm{g}^{-1}$ copper three times a week during one month. What can be the average concentration of copper in this person's body?

The adult body contains between 1.4 and $2.1 \mathrm{mg}$ of copper per kilogram of body weight $[17,18,19,20,21]$. Theoretical calculation and analysis indicating the necessity to avoid eating the fish caught here.

\section{CONCLUSIONS:}

Some chemical characteristics of the Mtkvari river were explored in two neighboring countries. The samples were extracted from Kars territory and from two sampling points in Tbilisi, at Vakhushti Bridge and Metekhi Bridge. During the research, analytical chemistry method, as well as high-tech studies, were applied. The outcomes obtained in the respective country were compared to applicable norms of Georgia, which in turn, are based on Euro standard parameters and are in compliance with the norms applicable in Turkey.

Based on the results, the river is contaminated according to some parameters, however, generally, it is within the limits specified 
in the standards. In Tbilisi samples there was a slight increase of copper ions and aluminum sulfate, indicating the necessity to avoid eating the fish caught here. However, there is no evidence of 'thiol poisons', zinc, cadmium, and mercury, which is a very important factor.

\section{REFERENCES:}

1. Technical Report "National Objectives for Integrated River Basin Planning and Management in Georgia". UNDP/Sida. Reducing Transboundary Degradation of the KuraAras River Basin. 2015.

2. William, A., David, E., A History of the Georgian people in the nineteenth century, Routledge \& Kegan Paul. 1971.

3. Kura. The Columbia Encyclopedia, Sixth Edition. 2005.

4. Kızılöz, B., Kupatadze, K. J. the Quimica. 2015,23, 47-55.

5. Kupatadze, K., Kızılöz, B. J. the Quimica. 2016. 26, 69-78.

6. http://nea.gov.ge/ge/home/

7. Bakir, B., Babayigit, M., Tekba, O. International Journal of Health Science and Research, 2015, 5, 257265.

8. Williams J., "Environmental Chemistry", J.Wiley \& Sons, Canada. 2012.

9. Sutton R., "Chemistry for the Life Sciences", Taylor\&Francis Group. 2008.

10. https://www.sakaaritim.com/ts-266inovasyon-standartlari/

11. Bhatia, S.C. "Environmental Chemistry", CBS Publishers and Distributors Pvt. Ltd, 2013.

12. Rawn, J., "General Chemistry", Wm. C. Brown Publishers, Oxford, England. 2004.

13. Decree of the Government of Georgia\#425, 2013, 31 December.

14. VanLoon, G. W. "Environmental Chemistry-a global perspective", Oxford Group, 2011.

15. Çicek , E. FishTaxa 1(1): 14-26. 2016.

16. Hashim, R., Han Song, T., Zuhartini, N. Trop Life Sci Res. 25, 2, 21-39. 2014.
17. Baynes, J., Dominiczak, M. Medical Biochemistry. Elsevier. 2014.

18. Usman,k., J.of Entomology and Zoology Studies.2017. 5 (6), 17261728.

19. Czédli, H., Csedreki, L., Fresenius Environmental Bulletin.2014. 7, 15471552.

20. Yang, $\mathrm{H}$., Li, J. Fresenius Environmental Bulletin. 2013. 22, 186193.4,

21. Abhijit, M., Ranju, C. Environmental Monitoring, and Assessment. 2012. 412. 
Continuance time=Total mass of copper /rate of intake

(Eq.1)

According (Eq.1), the rate of intake can be calculated as follows:

Rate of intake $=500 \mathrm{gr}$ fish $\times 0,5 \mu \mathrm{g} / \mathrm{g}^{-1}(\mathrm{fish}) \times 3 / 7 \mathrm{day}^{-1}=1.1 \times 10^{-1} \mathrm{mg}(\mathrm{Cu})$ day $^{-1}$

Continuance time $=$ Total mass of copper $/ 1.1 \times 10^{-1} \mathrm{mg}($ copper $)$ day $^{-1}$

From (Eq.3):

Total mass of copper=Continuance time $\times$ Rate of intake

Than

Total mass of copper $=30$ Day $\times 1.1 \times 10^{-1} \mathrm{mg}=329 \mathrm{mg}$;

The concentration of copper in the body is than: $329 \mathrm{mg}(\mathrm{Cu}) / 80 \mathrm{~kg}=4.1 \mathrm{mg} \mathrm{kg}^{-1}$

Table 1 Samples from Karsi

\begin{tabular}{c|c|c|c|c}
\hline index & Unit & $\mathbf{2 0 1 6}$ & $\mathbf{2 0 1 7}$ & $\mathbf{2 0 1 8}$ \\
\hline BOD & $\mathrm{mg} / \mathrm{l}$ & $0.70-4.00$ & $0.87-5.41$ & $0.75-6.52$ \\
\hline Mineralization & $\mathrm{mg} / \mathrm{l}$ & $222.00-311.3$ & $201.55-355.07$ & $147.00-498.44$ \\
\hline $\begin{array}{c}\text { Ammonium } \\
\text { nitrogen }\end{array}$ & $\mathrm{mg} / \mathrm{l}$ & $0.002-1.567$ & $0.367-1.345$ & $0.112-0.432$ \\
\hline $\mathbf{M g}$ & $\mathrm{mg} / \mathrm{l}$ & $<0.01$ & $<0.01$ & $<0.01$ \\
\hline $\mathbf{C a}$ & $\mathrm{mg} / \mathrm{l}$ & $<10$ & $<11,07$ & $<11,52$ \\
\hline $\mathbf{F e}$ & $\mathrm{mg} / \mathrm{l}$ & $10.01-29.53$ & $5.01-28.00$ & $8.15-28.12$ \\
\hline $\mathbf{M n}$ & $\mathrm{mg} / \mathrm{l}$ & $<1.00$ & $<1.00$ & $<1.03$ \\
\hline $\mathbf{C u}$ & $\mathrm{mg} / \mathrm{l}$ & $0.005-3.15$ & $0.02-3.75$ & $0.0171-2.98$ \\
\hline Sulfates & $\mathrm{mg} / \mathrm{l}$ & $1.00-4.00$ & $1.00-7.8$ & $1.00-4.87$ \\
\hline
\end{tabular}

Table 2. Samples from Vakhushi Bridge

\begin{tabular}{c|c|c|c|c}
\hline Index & Unit & $\mathbf{2 0 1 6}$ & $\mathbf{2 0 1 7}$ & $\mathbf{2 0 1 8}$ \\
\hline BOD & $\mathrm{mg} / \mathrm{l}$ & $0.81-5.81$ & $0.94-6.11$ & $0.75-7.93$ \\
\hline $\begin{array}{c}\text { Mineralization } \\
\text { ammonium } \\
\text { nitrogen }\end{array}$ & $\mathrm{mg} / \mathrm{l}$ & $230.1-426.3$ & $204.5-461.37$ & $147.73-527.42$ \\
\hline $\mathbf{M g}$ & $\mathrm{mg} / \mathrm{l}$ & $0.001-1.213$ & $0.257-1.174$ & $0.202-0.959$ \\
\hline $\mathbf{C a}$ & $\mathrm{mg} / \mathrm{l}$ & $0.0109-1.2356$ & $0.0023-1.78$ & $0.0016-1.1469$ \\
\hline $\mathbf{F e}$ & $\mathrm{mg} / \mathrm{l}$ & $20.15-334.45$ & $19.12-228,01$ & $19.67-151.67$ \\
\hline $\mathbf{M n}$ & $\mathrm{mg} / \mathrm{l}$ & $0.0012-3.1013$ & $0.0197-1.9315$ & $0.0010-2.7801$ \\
\hline $\mathbf{C u}$ & $\mathrm{mg} / \mathrm{l}$ & $0.0013-2.1683$ & $0.0047-1.1726$ & $0.0011-1.2729$ \\
\hline Sulfates & $\mathrm{mg} / \mathrm{l}$ & $0.002-1.1538$ & $0.0022-1.2548$ & $0.0153-0.1807$ \\
\hline
\end{tabular}

Table 3. Samples from Metekhi Bridge

\begin{tabular}{c|c|c|c|c}
\hline Index & Unit & $\mathbf{2 0 1 6}$ & $\mathbf{2 0 1 7}$ & $\mathbf{2 0 1 8}$ \\
\hline BOD & $\mathrm{mg} / \mathrm{l}$ & $0.73-4.94$ & $0.62-2.03$ & $0.54-4.24$ \\
\hline $\begin{array}{c}\text { Mineralization } \\
\text { ammonium } \\
\text { nitrogen }\end{array}$ & $\mathrm{mg} / \mathrm{l}$ & $251.5-420.7$ & $135.2-322.4$ & $114.5-447.2$ \\
\hline $\mathbf{M g}$ & $\mathrm{mg} / \mathrm{l}$ & $0.12-0.74$ & $0.257-0.824$ & $0.202-0.459$ \\
\hline $\mathbf{C a}$ & $\mathrm{mg} / \mathrm{l}$ & $32.40-$ & $9.53-41.78$ & $8.53-47.08$ \\
\hline $\mathbf{F e}$ & $\mathrm{mg} / \mathrm{l}$ & $16.15-378.00$ & $11.10-245.21$ & $18.15-390.00$ \\
\hline $\mathbf{M n}$ & $\mathrm{mg} / \mathrm{l}$ & $0.0015-2.1003$ & $0.0197-1.9315$ & $0.0097-1.9315$ \\
\hline $\mathbf{C u}$ & $\mathrm{mg} / \mathrm{l}$ & $0.1013-1.1782$ & $0.0047-1.1726$ & $0.0033-0.1700$ \\
\hline Sulfates & $\mathrm{mg} / \mathrm{l}$ & $0.005-1.1578$ & $0.0022-1.2548$ & $0.0023-1.3546$ \\
\hline
\end{tabular}

